\title{
Viewing of Women as Culture and Domain in "Perchavan" by Qaisra Shahraz
}

\author{
Shaista Andleeb ${ }^{1} \&$ Dr. Muhammad Asif Khan ${ }^{2}$ \\ ${ }^{1} \mathrm{PhD}$ scholar, Department of English, The Islamia University of Bahawalpur, Pakistan \\ ${ }^{2}$ Assistant Professor, Department of English, The Islamia University of Bahawalpur, Pakistan \\ Correspondence: Shaista Andleeb, Department of English, The Islamia University of Bahawalpur, Punjab, \\ Pakistan. E-mail: andleebshaista@gmail.com ordrasifkhan39@gmail.com
}

\author{
Received: September 3, 2020 Accepted: October 6, 2020 Online Published: October 26, 2020 \\ doi:10.5539/ells.v10n4p1 \\ URL: https://doi.org/10.5539/ells.v10n4p1
}

\begin{abstract}
Postcolonial Feminism serves as a critical thought to reset the idiom of suppression by identifying the cultural codes which involve women as the 'Other' in the Third World countries. This paper is an effort to point out the process of gender fixation in Pakistan which determines the cultural roles for women. This paper tries to define that the system of positioning of women in Pakistan, establishes the term women, as culture and domain. The paper tries to investigate the ideological problem in Pakistan for structuring the women's identity in their sexual cum biological caricatures in groups instead of their talents. The paper tries to explore that Qaisra Shahraz in "Perchavan" is trying to identify that the term 'women', initiates a debate on women not as the emblem of culture, yet women appear to be the culture themselves against all the ethnographic standards of gender remapping in any definition of culture. This study, about the Pakistani women, is an effort to show that Shahraz in "Perchavan" tries to expose, that women are treated as the culture in Pakistan. However, the women in the process of regional nomenclature become portable objects and ultimately they become the domain of society.
\end{abstract}

Keywords: postcolonial feminism, other, emblem of culture, gender remapping, women's identity, the idiom of suppression

\section{Introduction}

This paper tries to concentrate on the issue of women's marginalization in the name of womanhood in Pakistan. Qaisra Shahraz has tried to relocate the history of women's biological cum sexual duties in a family system in her story "Perchavan". The title of the story has its cultural significance, in the backdrop of women's identity in Pakistani society. The term 'perchavan' is related to a bad womb that cannot hold a child. This inability of holding a child by a woman becomes a cultural stigma for her. The term 'perchavan' is signified as a shadow of a woman who possesses a weak reproductive system. However, the belief behind 'perchavan' is related to the spiritual reasons for a miscarriage, rather than with some physical disabilities which can be cured. Anything physical for women is considered a prohibition in typical Pakistani society, especially in the village side. All that is left for the women are the superstitions. Shahraz in "Perchavan" is trying to show that women in the village side in Pakistan serve, as the strategic culture. Zaidi (2012) points out in this respect that, "tradition, ideology, and culture informed by patriarchal dogmas generate a set of beliefs which influence masculine and feminine identity formations" (p. 211) in Pakistan. The term 'perchavan' links a woman's body to the formation of the social understanding, regional association, and the power relationship. The story depicts the national, religious, and social structures in the regional areas of Pakistan, which are deliberately confiscating the women's identity in the name of culture.

Mohanty et al. (1991) point out that, "women are assumed to be sexual-political subjects before entry into kinship structure" (p. 61). Mohanty et al. (1991) further explain that it is the "effect of kinship structures, that women as women are constructed" (p. 61). Women are distributed in the regional societies as a gender group to which Mohanty et al. (1991) proclaim as the "monolithic notion of sexual difference" (p. 64). The notion of women as a group and sexual subjects is reiterated in "Perchavan" to reinforce the fact that women in a kinship structure constitute the borderline for the family sustenance. Marriage and children are the correlated subjects in the kinship structure which persuades women to act as the sexual group in Pakistan. Faiza's marriage is signified as a success if she gives birth to healthy children for her family/in-laws. Her sexual labor for her family is the 
only needful duty which she must perform to prove her gender dignity. On the other hand, Salama, who is befriended by Faiza, suffers from 'the loss of sexual labour' for her family. She remains infertile due to some gynecological problems. The difference between Salama's and Faiza's sexual subjectivity lies in the failure of playing the suggestive family role. Salama's biological attire is described in "Perchavan" as a symbol of insufficient sexual labour which results in a cultural myth of perchavan. If Salama's body cannot perform the prescribed sexual duty of bearing a healthy child, then it becomes a synonym of a bad culture. On the other hand, Faiza, who is pregnant with a child, is ordered by her mother-in-law, to keep herself away from Salama's shadow to avoid the bad effect of her body culture.

Beasley (2005) defines the term 'gender' as a "social process of dividing up people and social practices along the lines of sexed identities" (p. 11). She points out, the concept of sexed subjects as the part of the social system in naming men and women as the gender which "is commonly linked to social interpretation of reproductive biological distinctions" (p. 12). The domestic space, in which the mechanics of the sexed subject work, has its connection with the outside reality. Faiza's mother-in-law Kaniz is curious to have her grandchild. She is under the influence of a spiritual guide who is called a 'pir' (p. 37) in the native language.

The influence of the 'pir' and his instructions is so strong on Kaniz Bibi's conscious, that she forbids her daughter-in-law Faiza, to move freely outside home or to see any woman with 'perchavan'. She has a strong logic in doing so which is transferred to her by her pir, "My pir has especially tutored me to be aware of 'perchavan' affecting my daughter-in-law" (Shahraz, 2013, p. 37). Kaniz Bibi blindly follows her Pir's teachings. Shahraz has shown here, that the words of the pir become a religion for Kaniz Bibi. She shows her intimacy towards the religion when she uses the possessive pronoun for the pir i.e., "My pir" (p. 37). The 'pir' serves as the outside social reality, which gets easy access in the domestic space. Bhabha (1994) writes that "unhomely is a paradigmatic postcolonial and colonial condition" (p. 09).

Bhabha points out that, "Cultures recognize themselves through their projections of otherness" (1994, p. 12). He says that "the Other must not be imaged as a fixed phenomenon" (p. 51). He considers the "Other' as a "negation of a primordial identity" which sees culture as a "linguistic or symbolic historical reality" (1994, p. 52). Shahraz sees Salma as 'Other' who suffers from the negation of identity as a human being. In "Perchavan", Shahraz tries to promote through Salama's character, the influence of that symbolic historic reality outside the domestic spaces which defines Salama not as a woman but as a sexual body culture in herself. In other words, Salama and Faiza become the representative mouthpieces of sexual subjectivity within the domestic space as the opposites at the beginning of the text. However, both become equal sharers of a significant sexual subjection near the end of the text. Their unanimous condition at the end exposes them as the culture-specific 'Other'. The historic reality which determines the sexual subjectivity in the domestic space or a family is of the institutional category which persuades Kaniz to have a belief in women's reproductive disability.

Parveen and Qadir (2019) point out that, "Pakistan is a traditional patriarchal society which exhibits a marked preference for norms and values associated with supremacist androcentric ideologies" (p. 158).

This paper tries to explore that the term culture, is arbitrary in the context of gender construction in Pakistan. Women in Pakistan are represented by Shahraz in "Perchavan", as the organizers and sustainers of an outside historical reality just as in the case of Kaniz's and Faiza's. Salama and her mother are struggling to find a space to re-interpret the local domesticity of the term bad womb or perchavan. Both are trying to present a neutralized version of sexual subjectivity in the very realm of the nativity. On the other hand, Kaniz is a stereotypical mother-in-law who strongly believes in the superstitious version of women's sexuality. The concept of 'perchavan' and its significant effects on Pakistani women's lives represents a systematic refilling of the discriminated gender skeleton. This gender/sexual identification in the very concept of perchavan serves as the determiner of the women as culture or just leave them as the men's domain as the reproductive subjects.

\section{Objective of the Study}

The present study is aimed at reading the concept of culture and women as the fundamental structure of social formation in a Postcolonial country. The significance of the study lies in the investigation of the regional or native perceptions/superstitions in the Pakistani family system to relocate the social strategies to define women. The paper is an effort to search for those cultural symbols which are associated with a woman's body within the domestic space in Pakistan. In this respect, the paper tries to read the selected text Perchavan from its thematic perspective to identify the latent social hierarchies which are given to the Pakistani women. The idea of culture is taken up in this paper, as a tool to investigate that Pakistani women are marked with their reproductive capacities only and there is no other possible role available for them in their family system except being women. The paper aims at evaluating the text to disclose that women in Pakistan are viewed through certain conceptions and 
misconceptions which construct them as the historic truth and the native culture.

\section{Literature Review}

This paper is an effort to construct an argument on the Pakistani women's identity, not as an emblem of culture but as the sexual subjects. The paper tries to investigate the women's position as the conceived culture themselves on whose bodies the historical reality is developed. However, the paper is an effort to point out that Qaisra Shahraz is trying to highlight in her narratives about the socio-cultural indignation for the women in their preconceived social status to which they can raise their voices. The paper tries to explore that the story "Perchavan" retells the static condition of women in Pakistan as men's domain. Qaisra Shahraz in this story has tried to focus on showing the opposition between reality and superstitions which serve as the driving force of the social thought about women's roles. The story "Perchavan" is published in Shahraz's anthology, A Pair of Jeans and Other Stories (2013). The story serves as a portrayal of gender-specific superstitions that are associated with a woman's body in the Pakistani villages.

Chambers (2017) writes that "Qaisra Shahraz is a popular and acclaimed Pakistan-born and Manchester-resident screenwriter, educationalist, novelist and short story author" (p. 102). Shahraz in her introductory novels especially in The Holy Woman (2002) focuses on the silent themes in the Pakistan narrative culture. She tries to show the cover-up of Islamic and cultural compromise in its original sense in her stories. "Perchavan" discusses the negotiation between the native logic of Otherness and the religious justification of women's identity. Siddiqui (2014) observes in this context that, "Qaisra does not shy away from speaking on some contentious issues like the confusion of the tribal and the Islamic in popular imagination" (p. 216).

Menon (2012) writes about Shahraz that "Most of her works have women as protagonists-Women victimised by society, but who fight back with an unyielding spirit". Zaidi (2012) observes that Shahraz, "in her narrative criticizes fundamentalist obsession with traditional gender relationships and the role of women as transmitters of culture and religion" (p. 210). Parveen and Qadir write that, "The contemporary female writers like Qaisra Shahraz critique and challenge institutionalized discourses which result in gender discriminatory practices" (pp. 158-159).

Ahmed (2009) observes that "Tradition and culture is still very strong and the misogynic tendencies though curbed yet not have been totally removed" in Pakistan (p. 189). He points out, the exposition of women's victimization through the implications of the tradition, in Shahraz's novel Typhoon (2003). He writes that the women in the novel are projected as the suppressed beings in the hands of men and the traditions. He relates the women's suppression in Shahraz's narrative as the direct result of submissive admiration of the native decisions on gender roles. This passive admission of the cultural norms results in the women's sufferings who suffer "not only physically but also mentally and become victims of their own hallucinations" (p. 189).

\section{Research Methodology}

This paper tries to investigate the Pakistani women's status as Third World subjects. The paper focuses its analysis on critically evaluating, Qaisra Shahraz's short story "Perchavan". Postcolonial Feminism serves as the theoretical framework for the identification of the Pakistani women's identity as culture and domain in this paper The paper tries to find its scope in the theoretical ramification of the Postcolonial Feminism to discover that Pakistani women are considered, the institutionalized products of family and society. The qualitative approach is used for this exploratory research. The method of close readings is applied to this study.

The paper follows the APA style of writing. The theory of Postcolonialism Feminism is taken up as a theoretical background for this study. Homi, K. Bhabha, and Gayatri Spivak serve as the major Postcolonial theorists for this paper to explore the meanings of culture and women in the selected text. The idiom of 'Home' and 'Otherness' is dealt with in this paper, to investigate the effectiveness of the same in a Postcolonial text to relocate the ideology and culture of suppression. In this context, this paper takes the term 'Home', as the 'domestic space' and the term 'Otherness' is taken up as 'the sexed-subjects'.

Spivak (1990) points out that, "Textuality is tied to discourse itself in an oblique way" (p. 01). Spivak as a Postcolonial Feminist resists the Western concerns of the Third World women as the ethnographic representation. Spivak (1990) proclaims that "the imperialist project which had to assume that the earth that it territorialised was in fact previously uninscribed" (p. 01). This intellectual presumption about the generalization of the Third World by the imperialist project is inscribed, through the Western discourse of desire. The Western desire in the intellectual discourses of the West is traced in the subjective positioning of the Third World women. Spivak points out to a reference here that, "the constitution of the sexed subject in terms of the discourse of castration was, in fact, something that came into being through the imposition of imperialism" (1990, p. 09). 
Spivak (1990) is interested in making a 'heterogeneous production of the sexed subjects' (p. 10). She insists on focusing on "the female subject-constitution" $(1990$, p. 10) as the focal point of interest in the Postcolonial Feminism. Bhabha (1994) writes in this context that, "The representation of difference must not be hastily read as the reflection of pre-given ethnic or cultural traits" (p. 02). In this respect, Bhabha (1994) comments that "The recesses of the domestic space become sites for history's most intricate invasions" (p. 09). The identification of these intricate invasions by the colonial history on the domestic space, to which Bhabha points out, is the fixation of women's roles as the sexed-subjects. Suleri (1992) reiterates the same point when she manifests, "the gender imbrication implicit in the classification of culture as an anxious provenance partitioned between the weakness and strength of men" (p. 17). The active inheritance of the gender classification to the local family system produces passive receptors of the culture-specific sexual subjects.

\section{Discussion}

This paper is an attempt to analyze the short story "Perchavan" by Qaisra Shahraz from the perspective that women in Pakistan do not represent their native culture rather they are the culture themselves. In this respect, Spivak (1985) is critical in her stance about the hegemonic approach of literature towards defining the Third World woman as the signifier of subjugation. She points out in her acclaimed essay Three Women's Texts and a Critique of Imperialism (1985) about the historic influence of imperialism on the definition of culture in literature. Spivak (1985) criticizes the role of the Postcolonial literature which is "driven by a nostalgia for lost origins" (p. 245). She stresses the recognition of the systematic exploitation of the imperialist discourse which projects the ethnography of nativity with a subversive dignity. Spivak (1988) shares her concerns about the most "problematic concerns" in Postcolonial feminism i.e., "woman" (p. 90) in her arguments about the Imperial suggestiveness. She points out, the Imperial strategies to impose Otherness on the Third World which are juxtaposed in the socio-political determination of the class-gender relationship. In this respect, she observes that "Not only a civil but a good society is born out of domestic confusion" (1988, p. 93).

Shahraz in her story "Perchavan" tries to portray the native women's culture from its domestic preferences of womanhood to feministic sexual disorder. This paper tries to investigate how the native Pakistani women become the synonyms of culture as the sexual subjects in their domestic roles. The story "Perchavan" is about the native concept of a woman who suffers from the curse of miscarriage and is considered an evil-shadowed woman. Naz and Batool (2017) point out that "In Pakistan manhood is equated with fatherhood; and womanhood with motherhood" (p. 01). However, the women's role as the reproductive objects is far more significant in a Pakistani family system as compared to the men. The women must produce healthy children after marriage. In this respect, Naz and Batool (2017) write that, marriage is considered in Pakistan, "as a vehicle to conceive and bear children" (p. 01). Any woman, who fails to produce a child after marriage, is considered an infertile woman. The infertile woman is named as the barren earth which is unable to produce food.

"Perchavan" retells the Pakistani women's plight as the sexual subjects who have to perform their biologically sexual roles in the prescribed family spaces. The concept of 'perchavan' is associated with the sexual powerlessness of women. Naz and Batool point out that, "Pakistanis consider children as a symbol of fortune for the parents, the source of pride" (p. 01). If a woman in Pakistan is unable to give the pride of the family in the form of children to her husband, she becomes an alien for her in-laws. The infertility issue is addressed in the story "Perchavan" to expose the historical reality of the Otherness. The narration of the story defines the system of culture construction through women's sexual roles in Pakistan. Shahraz has tried to show in this story that the concept of 'perchavan' in the Pakistani nativity is related to the superstitious concerns of a gendered society. Faiza's miscarriage is due to her slipping from the wet floor. However, Salama's position becomes confrontational with her presence on the same spot, and she is blamed by Kaniz Bibi for Faiza's miscarriage, "Our healthy daughter-in-law suddenly miscarries the very next day after embracing a woman with a perchavan" (p. 43). On the other hand, Salma's derogatory condition gets worst by Kaniz Bibi's consistent taunts on her perchavan ridden identity. Kaniz Bibi calls Salma, a "namoush" (p. 43). 'Namoush' is a local term that is used for a shameless woman. Salama is blamed by Kaniz Bibi for spreading her perchavan on Faiza's body, "just because she keeps miscarrying herself" (p. 43).

Shahraz tries to show in this story that the concept of 'perchavan' works as an active transition like that of a consistent ritual in a Pakistani village. However, this ritual of 'perchavan' is somehow associated with the physical touch by any woman who has the evil-shadow of infertility. The story "Perchavan" has its second perspective which describes the rationale of the concept of perchavan in a religious and non-native way. Shahraz becomes an anti-traditionalist in her criticism of the concept of 'perchavan' through Zeinab's character. She questions the range of superstitions and disbelief which diagnoses and ascribes any woman with a disgraceful cultural attribute of perchavan. Salama's mother Zeinab rejects Kaniz Bibi's traditional ideas about a woman's 
body, which are inculcated by her through the persistent tutoring of her pir. Through Zeinab's words of defiance, Shahraz seems to throw away the intricacies of the patriarchal system and its political ramifications. Zeinab asks Kaniz Bibi if she knows that the concept of 'perchavan' comes from "the Quran or Hadith" (p. 45) or this concept simply comes from the pir? Shahraz criticizes the native series of misconceptions in her act of identification of the same in the story "Perchavan". She tries to portray that the patriarchal system coins misconceptions and spreads superstitions among women to sustain their patronage of the Otherness.

In this respect, Shahraz identifies the term perchavan as a man-made phenomenon to subdue women to keep them busy in their sexual roles. This becomes a textual fact when Salama felt "damned, soiled, inadequate, belittled and insulted" (p. 39) after being blamed for Faiza's miscarriage due to her perchavan. On the other hand, Zeinab questions Kaniz Bibi, "Where has the pir got his ideas from? Is he a woman? Is he a doctor? Is he an authority on all-female health matters?" (p. 47). Zeinab challenges the credibility of the Pir's ideology about women's matters and advises Kaniz Bibi to think rationally about Faiza's miscarriage. Even the midwife knows about the reason behind Faiza's miscarriage, but the 'perchavan' culture is the most credible social fact to which she cannot negate due to its infusion in a domestic space by a holy man. Zeinab tries to pacify Kaniz's anger against Salama but she cannot fill the gap of superstitions which has been dig by the spiritual guide in her mind. Zeinab criticizes Kaniz for humiliating Salama for being an infertile woman. She tries to evoke Kaniz's consciousness on women's sensibilities which are different from men's so-called rationalism. She says, "You have harmed and hurt young minds of women like my daughter" (p. 45). Zeinab blames Kaniz Bibi who, "have belittled" Salama for nothing and in her doing so she has "insulted the whole essence of humanity and womanhood" (p. 45). However, Zeinab finishes her conversation with Kaniz by saying, "As you have made the rules. Perchavan is now in your house" (p. 46). Zeinab criticizes Kaniz that, "Your daughter-in-law has miscarried, according to your rules no household with a pregnant woman should welcome her" (p. 46). Here, Shahraz is trying to do poetic justice with the system of superstitions, in Zeinab's retort to Kaniz Bibi, "Now it is your Faiza who will be the one to be shunned. You cannot have it both ways" (p. 46).

\section{Conclusion}

This paper is concluded with the findings that the story "Perchavan" refers to a native term which is used for the women who are considered as reproductive failures or infertile. The term 'perchavan' refers to a social belief in a contagious feminine disease that is coined by the patriarchal system in Pakistan. The reference to the 'Pir' is an explicit example of patriarchy in this story. The 'Pir' serves as an active socio-patriarchic agent to promote gender discrimination and hatred among illiterate masses. The paper concludes that Shahraz has objected to the traditional and socio-religious interpretations of Islamic teachings. The paper finds out that Shahraz tries to show that the concept of 'perchavan' and its related social significance is not proven from the Islamic perspective. With a reference to the epistemological truth, Shahraz in "Perchavan" tries to initiate a debate on religious rethinking about women's affairs in Pakistan. The paper sums up through the textual observation that the title of the story "Perchavan" is intentionally left un-translated by Shahraz to signify its native preference in gender structuring to promote Otherness. The paper finds out that the native preferences to the superstitions like 'perchavan' are deliberately promoted by the men to form a power structure in the name of culture through the sexual subjects within the domestic space.

\section{References}

Ahmed, Z. (2008). Status of Women in Pakistani Fiction in English: A Study of Pakistani Feminist fiction. Unpublished Doctoral Dissertation. The Islamia University of Bahawalpur, Bahawalpur.

Beasley, C. (2005). Gender and Sexuality: Critical Theories, Critical Thinkers. London: Sage Publications.

Bhabha, H. (1990). Dissemination: Time, Narrative, and the Margins of the Modern Nation: In Nation and Narration. New York: Routledge.

Bhabha, H. (1994). The Location of Culture. New York: Routledge.

Chambers, C. (2017). Qaisra Shahraz in Interview with Clair Chambers. Asiatic, 11(2). Retrieved from https://www.eprints. Whiterose.ac.uk

Menon, A. (Feb, 01, 2012). From the Woman's Point. The Hindu. Retrieved from https://www.thehindu.com

Mohanty, C. T., Russo, A., \& Torres, L. (Eds.). (1991). Third World Women and the Politics of Feminism. USA: Indiana University Press.

Naz, B., \& Batool, S. S. (2017). Infertility Related Issues and Challenges: Perspectives of Patients. Spouses, and Infertility Experts. Pakistan Journal of Social and Clinical Psychology, 15(2), 3-11. 
Shahraz, Q. (2002). The Holy Women. Pakistan: Alhamra Publishing.

Shahraz, Q. (2003). Typhoon. Islamabad: Alhamra Publishing.

Shahraz, Q. (2013). A Pair of Jeans and Other Stories. London: HopeRoad.

Siddique, M. A. (June, 2014). An Interview with Qaisra Shahraz. Asiatic, 8(1), 215-227.

Spivak, G. C. (1988). Can the Subaltern Speak? In C. N. Grossberg (Ed.), Marxism and the Interpretation of Culture. Urbana: University of Illinois Publishers.

Spivak, G. C. (1985). Three Women Texts and a Critique of Imperialism: A Critical Inquiry. Chicago Journals, $12,243-261$.

Spivak, G. C. (1990). The Postcolonial Critic: Interviews, Strategies, Dialogues (Harasym, S. Ed.). New York: Routledge.

Suleri, S. (1992). The Rhetoric of English India. London: The University of Chicago Press.

Zaidi, N. A. (2012). From Victim to Survivor: A Critical Study of Qaisra Shahraz's The Holy Woman. Pakistan Journal of Women's Studies: Alam-e-Niswan, 19(2), 209-223.

\section{Copyrights}

Copyright for this article is retained by the author, with first publication rights granted to the journal.

This is an open-access article distributed under the terms and conditions of the Creative Commons Attribution license (http://creativecommons.org/licenses/by/4.0/). 